\title{
Mammary carcinoma in a mare: clinical, histopathological and steroid hormone receptor status
}

\author{
Fulvio Laus' ${ }^{1}$, Francesca Mariotti', Gian Enrico Magi ${ }^{1}$, Daniele Spaziante', Maria Carlotta Fugazzola² and Beniamino Tesei ${ }^{7}$ \\ Veterinary Sciences Department, Faculty of Veterinary Medicine, Camerino University, Matelica (MC) Italy and Klinik fur Pferde, Stiftung Tierärztliche Hochschule \\ Hannover, Hannover, Germany²
}

\begin{abstract}
Summary
The aim of this paper is to describe the clinical, histopathological and immunohistochemical findings of a mammary carcinoma in a 22 year-old, 10 month pregnant, thoroughbred mare. The clinical examination of the right mammary gland showed a firm enlargement and purulent discharge from the ulcerated skin surface and the teat. During necropsy visceral metastases were not found but inguinal lymph nodes presented metastatic infiltrations when observed histologically. None of the previous reports found positive immunohisthochemical reactions for estrogen and progesteron receptors in an equine mammary adenocarcinoma. However, the findings of positive immunoreactivity to steroid receptors could suggest a hormonal influence on the genesis of the mammary neoplasm, as demonstrated in human breast cancer.
\end{abstract}

Keywords: mare, carcinoma, mammary gland, immunohistochemistry, steroid hormone receptors

Karzinom der Milchdrüse bei einer Stute: klinische und histopathologische Befunde: Nachweis von Steroidhormonrezeptoren

Mammatumoren kommen häufig bei Hunden und Katzen vor, selten bei anderen Haustieren. Beim Pferd sind nur wenige Fälle von Neoplasien des Gesäuges beschrieben, erstmals 1926 von Surmont. In den sporadischen Fällen werden Mammarkarzinome beschrieben, die oft lokal invasiv wachsen und dazu neigen, in andere Organe zu metastasieren. Bei keinem der bisher publizierten Fälle von malignen Gesäugetumoren wurde ein positiver immunohistochemischer Nachweis von Steroidhormon-Rezeptoren geführt. Dieser Fallbericht beschreibt ein Mammakarzinom bei einer 22-jährigen, im 10. Monat tragenden, nicht laktierenden Vollblutstute mittles klinischer, zytologischer, histopathologischer und immunohistochemischer Untersuchungstechniken. Vorberichtlich zeigte die Stute schlechten Allgemeinzustand, Anorexie und Ödeme am ventralen Abdomen und an den Hintergliedmaßen. Bei der klinischen Untersuchung wies das rechte Gesäuge eine derbe Umfangsvermehrung auf und war bei der Palpation schmerzhaft. Purulenter Ausfluss war sowohl aus der ulzerierten Haut als auch aus der Zitze zu beobachten. In einer Probe des Sekrets konnte nach Kultivierung Streptococcus dysgalactiae subsp. equisimilis isoliert werden, der bei einem Resistenztest sensibel auf Penicillin G war. In einer mit einer Kanüle durchgeführten Aspirationsprobe vom Mammagewebe waren Zellen des roten und weißen Blutbildes vorhanden. Bei der sonographischen Untersuchung des rechten Gesäuges konnte ein heterogenes Aussehen des Drüsengewebes mit nur wenig physiologischem Parenchym, hyperechogene Bereiche und einige runde bis ovoide hypoechogenen Bereiche dargestellt werden. Bei der Sektion wurden keine Metastasen in anderen Organen gefunden, jedoch konnten histologisch Metastasen in den inguinalen Lymphknoten beobachtet werden. Eine positive Immunoreaktion auf Progesteronrezeptoren wurde bei 35-40\% der neoplastischen Epithelzellen festgestellt. In dem noch gesundem Gesäugegewebe gab es eine positive Reaktion auf Östrogenrezeptoren und auf Progesteronrezeptoren. Dieser erste Fall eines positiven immunhistochemischen Steroidhormonrezeptornachweises beim Pferd könnte für einen hormonellen Einfluss bei der Genese der Mammatumoren sprechen, wie es bei Mammatumoren des Menschen bekannt ist.

Schlüsselwörter: Stute, Adenokarzinom, Euter, Immunhistochemie, Steroidhormonrezeptoren, Mammakarzinom

\section{Introduction}

Mammary tumours are common in dogs and cats but are very rare in other domestic animals (Wilkock 1993, Theilen and Madewell 1979). There are only a few reports of mammary gland tumors in horses, the first case was reported by Surmont in 1926. Sporadic reports described mammary carcinomas often growing strongly and locally invasive and spreading into other organs (Schmahl 1972, Acland and Gillette 1982, Munson 1987, Foreman et al. 1990, Seahorn et al. 1992, Reppas et al 1996, Kato et al 1998, Prendergast et al. 1999, Hirayama et al 2003). None of the previous reports described positive immunohisthochemical reactions for estrogen and progesteron receptors of mammary carcinomas (Seahorn et al. 1992, Reppas et al. 1996). A few positive neoplastic cells were recently found in a mammary adenoma (Spadari et al. 2008). In our report, a mammary carcinoma in a preg- nant, non lactating thoroughbred mare has been examined clinically and with cytological, histopatological and immunohistochemical techniques.

\section{Case report}

A 22-year-old, 10 month pregnant, non-lactating, thoroughbred mare has been presented to our clinic because of poor condition, anorexia and a progressive enlargement of the mammary gland. At the clinical examination the mare was cachectic, depressed, dehydrated and febrile $\left(40.1^{\circ} \mathrm{C}\right)$. The right mammary gland showed a firm enlargement and purulent discharge from the ulcerated skin surface and the teat (Figure 1). At palpation the mass had irregular shape, fibrous consistency and was painful, whereas the left mammary gland 
was normal. Oedema of the ventral abdomen and hind limbs was present. Haematological examinations revealed marked leucocytosis $(22,100 / \mu \mathrm{l})$ with neutrophilia $(20,700 / \mu \mathrm{l})$ and inverted albumin/globulin ratio. Cytologic evaluation of the mammary secretion revealed the prevalence of degenerated neutrophils, some macrophages, lymphocytes, plasma cells and coccoid intracellular and extracellular bacteria. A sample of mammary secretion was cultured and Streptococcus dysgalactiae subsp. equisimilis was isolated, susceptible to penicillin $\mathrm{G}$. Fine needle aspiration of the mammary tissue revealed blood and inflammatory cells.

Ultrasonographic examination of the right mammary gland showed a heterogeneous appearance with little normal parenchyma, hyperechoic parts and some round to ovoidal

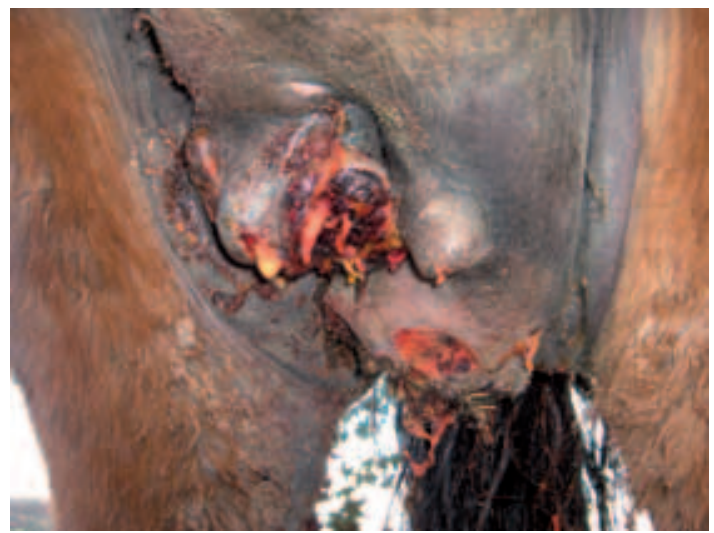

Fig. 1 Enlarged and ulcerated right mammary gland in ventral view. Note the purulent material discharging from ulcerated surface and the teat.

Umfangsvermehrtes und ulzeratives rechtes Gesäuge, ventrale Ansicht. Purulentes Exsudat tritt aus der ulzerierten Oberfläche hervor.

hypoechoic areas (Figure 2). A specimen obtained by needle biopsy was histologically examined and it showed the presence of abundantly vascularized granulation tissue and some inflammatory cells, mainly lymphocytes and plasma cells. A presumptive diagnosis of suppurative mastitis was made. After administration of penicillin $(10,000 \mathrm{UI} / \mathrm{Kg}$ IM every 12 hours) and flunixin meglumine (1,1 mg/Kg IV every 24 hours) mammary enlargement and purulent discharge regressed slightly but the general condition worsened. Neoplasia was suspected on the basis of clinical findings, poor response to the therapy and ultrasonographic appearance with hypoechoic areas probably consistent with tumour necroses. Surgery was not performed because of the mare's poor condition and according to the owners wishes. Parturition was induced but the foal died within 30 minutes after birth. The mare was euthanized on owner's request.

On the cut section the right mammary gland revealed many yellowish necrotic foci of variable size in the outer area and was scattered with white firm tissue in the inner area. The superficial inguinal lymph nodes were enlarged. Tissue samples were collected from the spleen, liver, kidneys, adrenal glands, ovaries, lungs, heart and brain.

Samples were fixed in 10\% neutral buffered formalin, paraffin embedded, sectioned at $4 \mu \mathrm{m}$, and used for hematoxylineosin staining. For immunohisthochemical (IHC) examination, the sections were deparaffinized and endogenous peroxidase activity was quenched. The slides were steamed twice in 8minute cycles in $10 \mathrm{mM}$ citrate buffer, $\mathrm{pH}$ 6.0, using a microwave (750 Watts) for antigen retrieval, then incubated with the following antibodies using the avidin-biotin peroxidase method (Vector Laboratories, Inc., Burlingame, CA, USA): cytokeratin AE1/AE3 (1:100; Dako Corp., Carpinteria, CA), vimentin V9 (1:100; Dako Corp., Carpinteria, CA), Ki-67 (1:100; Dako Corp., Carpinteria, CA), estrogen receptor-alfa (Ers- $\alpha)$ (1:100; Santa Cruz Biotech, CA), estrogen receptorbeta (Ers- $\beta)(1: 100$; Santa Cruz Biotech, CA) and progesteron receptor (PR) (1:100; Santa Cruz Biotech, CA). The reaction was visualized with 3,3'-diaminobenzidine chromogen and the sections were counterstained with $0.1 \%$ hematoxylin (Sigma, St. Lovis, MO), dehydrated and mounted. The staining of

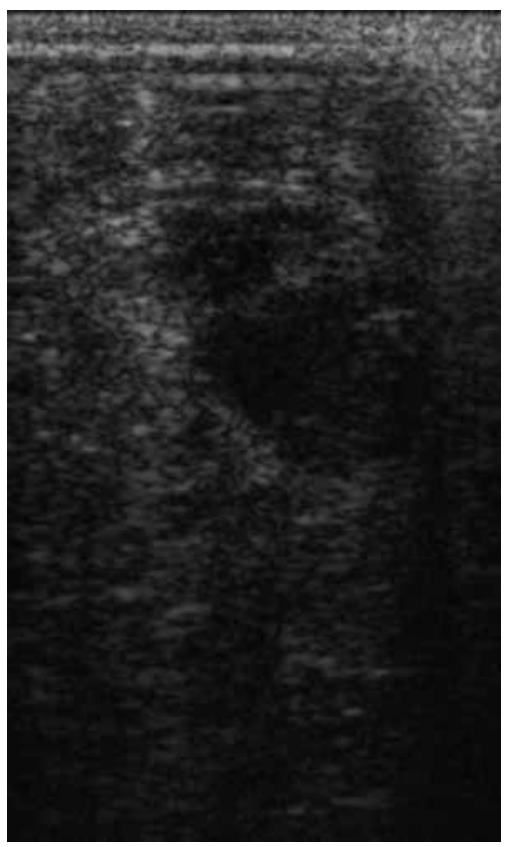

Fig. 2 Ultrasonographic appearance of the affected mammary gland. Note the heterogeneous appearance with hypoecoic areas partially surrounded by fibrotic tissue and, in the distal portion, some nearly normal parenchyma.

Ultrasonographie des betroffenen Euters. Heterogenes Gesamtbild mit hypoechogenen Bereichen, teilweise von fibrotischem Gewebe umgeben. In dem distalen Teil unverändertes Parenchym.

no-specific controls was the same except for substitution of the primary antibody with pre-immunization mouse serum.

Microscopic examination of the mammary mass revealed a simple carcinoma with massive necroses and suppurative inflammation. The neoplastic tissue was mainly characterized by irregularly shaped islands and sheets of epithelial cells. Solid pattern and papillary ingrowths of neoplastic cells were also present as well as cyst-like structures filled with proteinaceous fluid and necrotic debris. The neoplastic cells appeared polygonal in shape and showed round to oval vesicular nuclei with peripheral chromatin and prominent, often multiple, nucleoli. Five to six mitotic figures per high power field (x40) were observed. Cytoplasm was abundant, eosinophilic and often vacuolated. Lymphatic invasion was evident and sheets of neoplastic cells infiltrated the surrounding stromal tissue. According to $\mathrm{WHO}$ classification, the tumour corresponds to a simple carcinoma solid type, with focal tubulopapillary pattern. Follicular aggregated clusters of lymphocy- 
tes were present in and around the neoplastic lobules and ducts, and around blood vessels, with and without germinal centres. Many inflammatory cells, mainly neutrophils, were found in interstitial spaces and around the areas of necroses. Metastases to the enlarged regional lymph nodes were found microscopically.

At IHC examination, the tumour cells showed virtually homogeneous A1/A3 cytokeratin expression throughout the entire sample while the number of $\mathrm{Ki}-67$ positive cells ranged from 50 to $75 \%$. Immunolabelling for $\alpha$ ERs was observed in 45$50 \%$ of neoplastic cells varying between different areas. The positive cells showed a nuclear and cytoplasmatic brown, finely granular appearance. The intensity of $\alpha E R s$ immunore-

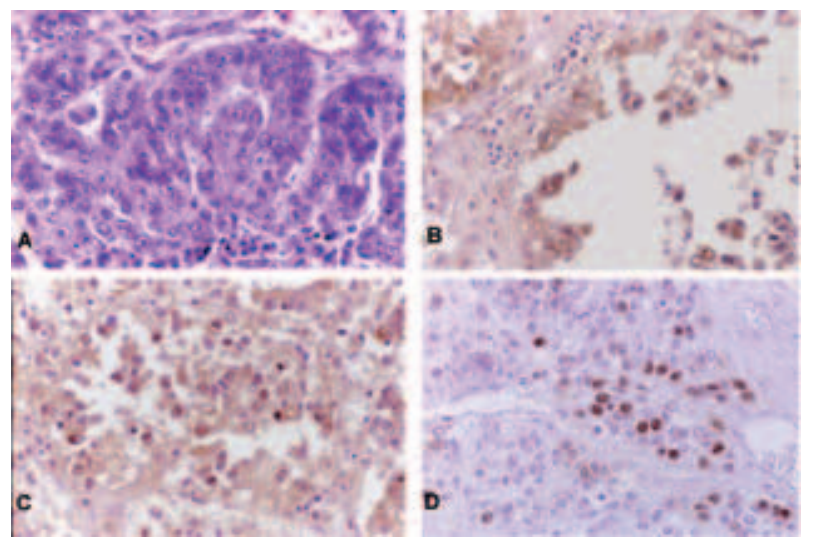

Fig. 3 Histopatological and immunohistochemical appearance of mammary carcinoma. A: EE, 40X. B: immunostain for ER- $\alpha$, 40X. C: immunostain for ER- $\beta$, 40X. D: immunostain for Ki-67, 40X

Histopathologisches und immunohistochemischse Aussehen des Mammakarzinoms. A: EE, 40X. B: immunostain für ER- $\alpha, 40 X$. C: immunostain für ER- $\beta, 40 X$. D: immunostain für Ki-67, 40X

activity ranged from moderate to intense. The percentage of $\beta$ ERs positive cells was similar to $\alpha$ ERs but staining intensity ranged from slight to moderate. Neoplastic cells with marked atypical morphology showed a weaker staining intensity to $\alpha$ and $\beta$ ERs (Figure 3). PR immunoreactivity was found in 35$40 \%$ of epithelial neoplastic cells (Figure 4). In a few foci of normal mammary tissue, a positive reaction to ER- and PRreceptors was found. The metastases in lymph nodes were immunohistochemically negative to $\alpha$ - and $\beta$-estrogen receptors and progesterone receptors.

\section{Discussion}

Mammary carcinoma is a rare neoplasm that affects older mares 12 and 25 years of age (Schmahl 1972, Acland and Gillette 1982, Munson 1987, Foreman et al. 1990, Seahorn et al. 1992, Reppas et al. 1996, Kato et al. 1998, Prendergast et al. 1999, Hirayama et al. 2003). The cases in which the breed was reported included $5(35,7 \%)$ Thoroughbreds, $5(35,7 \%)$ Quarter Horses, 2 (14,3\%) Arabians, 1 (7,1\%) pony and $1(7,1 \%)$ Irish draught but the number of reported cases is too little for ruling out an epidemiological conclusion about incidence in different breeds.

A recurring clinical characteristic of mammary carcinoma is ulceration of the skin covering the affected mammary gland (Foreman et al. 1990, Seahorn et al. 1992, Prendergast et al.
1999, Hirayama et al. 2003). This finding was very obvious in our case and could help in distinguishing malignant mammary neoplasms from mastitis or adenoma which do not show this feature (McCue and Wilson 1989, Spadari et al. 2008). On the contrary, pain (as was present in our case) is not a distinctive feature of carcinomas and has been reported also in mastitis and adenoma (McCue and Wilson 1989, Spadari et al 2008).

The mare of our report had hind limb oedema but this finding in our case was not associated with the spread of the tumour into the inguinal canal as reported by other authors (Munson 1987, Prendergast et al. 1999). The edema in our case could be due to decreased serum protein or to disturbed lymphatic drainage.

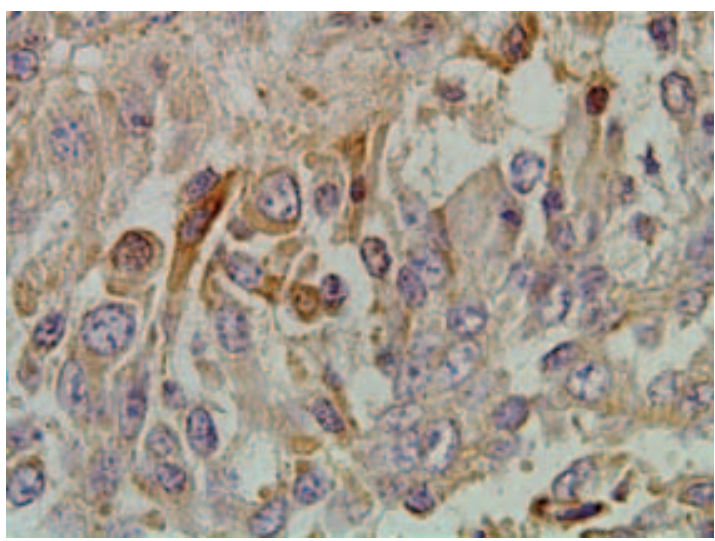

Fig. 4 Histopatological and immunohistochemical appearance of mammary carcinoma. Immunostain for PR, 40X.

Histopathologisches und immunohistochemischs Aussehen des Mammakarzinoms mit Immunstain für PR, $40 \mathrm{X}$.

Data of haematological analysis were reported in only five cases. One mare had neutrophilia and lymphopenia (Reppas et al. 1996) and all the three cases reported by Prendergast et al. (1999) had hypoalbuminemia and hyperglobulinemia with one presenting moderate leucocytosis with neutrophilia. One case (Kato et al. 1998) showed increased glutamic oxaloacetic transaminase, $\gamma$-glutamil transpeptidase and $\gamma$-globulin and reduced albuminemia, but this mare was affected by a hepatic carcinoma as well. Our results match some of the previous findings, like leucocytosis, neutrophilia, hyperglobulinaemia and hypoalbuminaemia. Leucocytosis and neutrophilia could be due to the secondary infection; hyperglobulinaemia was probably due to the effect of chronic inflammation while hypoalbuminaemia could correlate with starvation or protein loss from the ulcerated skin, as suggested by Prendergast et al (1999).

Since equine mammary neoplasm is a rare disease, very little ultrasonographic data of mammary carcinoma is available from literature. However, the heterogeneous sonographic appearance is common in malignant neoplasms and hypoecoic areas could suggest suppurative infection and/or tumor necrosis (Reef 1998).

Unlike mentioned in other reports (Prendergast et al. 1999, Freeman 1993, Larkin 1994) fine needle aspiration has not been useful in our case in distinguishing mastitis from mammary carcinoma. Because of the extent of the inflammatory reactions and necroses, fine needle aspiration and needle 
biopsy can sometimes obtain unrepresentative samples; on the other hand, histopathology is the only tool to achieve an accurate diagnosis.

Equine mammary carcinoma can be locally invasive, involve local lymph nodes or metastasize into the lungs, pleura, kidneys, ovaries, spleen, liver, adrenal glands and mediastinal, bronchial and mesenteric lymph nodes (Schmahl 1972, Acland and Gillette 1982, Munson 1987, Foreman et al. 1990, Seahorn et al. 1992, Reppas et al. 1996, Kato et al. 1998, Prendergast et al. 1999, Hirayama et al. 2003). In our case the tumor involved only the local lymph nodes; no systemic signs of metastases were clinically noted as in other reports (Foreman et al. 1990) and no metastases were macroscopically found at necropsy.

The histological characteristics of the tumour were similar to the canine common invasive carcinoma of solid type with areas of tubular differentiation. This appearance was different to other mammary tumours in the mare in which the arrangement of neoplastic cells was mostly tubular (Hirayama et al. 2003, Prendergast et al. 1999). On the other hand, cellular atypism, high mitotic index, stromal and vascular invasion, metastatic lesions and secondary mastitis where reported also in other cases (Hirayama et al. 2003, Marxfeld 2005). To our knowledge, steroid receptors were sometimes investigated (Seahorn et al. 1992, Reppas et al. 1996) but until now never detected immunohistochemically in equine mammary carcinoma.

The ascertained positive immunoreactivity to $\alpha$ - and $\beta$-estrogen receptors could suggest a possible hormonal influence on the genesis of equine mammary neoplasms as demonstrated in human oncology. Experimental and clinical data have demonstrated the importance of estrogen receptors in the development and progression of breast cancer which has made them a major target for cancer treatment (Saji et al. 2002). Furthermore, estrogen receptor status is generally associated with more differentiated and less invasive tumours, suggesting that it may have a protective role against metastatic progression (Platet et al. 2004).

In veterinary medicine, a rapid loss of ERs in feline mammary tumours has been demonstrated (Millanta et al. 2006). On the contrary, the dog tends to mantain ERs also in malignant tumours and levels of receptors can be significantly higher in carcinomas admixed with normal tissue than in "pure" carcinomas (Meuten 2002). The role of PRs in the mare could be the same as in the dog and in the woman (Rutteman et al. 1988).

Regional and distant metastases are frequently negative to hormonal receptors, indicating that in advanced diseases the expression of genes encoding ERs and PRs is lost (Rutteman and Misdorp 1993).

Since Prendergast et al. (1999) did not notice prolongation of survival using surgery when compared with conservative therapy, these markers in the mare (as in other species) could be a useful tool not only for prognostic evaluation but also for hormonal/anti-hormonal treatment, associated or alternative to surgical excision. More investigation will be necessary to verify this hypothesis. The malignancy and invasiveness of mammary carcinoma in our work, associated with metastasis to regional lymph nodes, carry a grave prognosis.

\section{References}

Acland H. M. and Gillette D. M. (1982) Mammary carcinoma in a mare. Vet. Pathol. 19, 93-95

Foreman J. H., Weidner J. P., Parrym B. W. and Hargis A. (1990) Pleural effusion secondary to thoracic metastatic mammary adenocarcinoma in a mare. J. Am. Vet. Med. Assoc. 197, 1 193- 1195

Freeman K. P. (1993) Cytological evaluation of the equine mammary gland. Equine Vet. Educ. 5, 212-213

Hirayama K., Honda Y., Sako T., Okamoto M., Tsunoda N., Tagami M. and Taniyama H. (2003) Invasive ductal carcinoma of the mammary gland in a mare. Vet. Pathol. 40, 86-91

Kato M., Higuchi T., Hata H., Ishikawa Y. and Kadota K. (1998) Lactalbumin-positive mammary carcinoma in a mare. Equine Vet. J. 30, 358-360

Larkin H. (1994) Veterinary cytology, fine needle aspiration of masses or swellings on animals. Irish Vet. J. 47, 65-73

Marxfeld H. (2005) Gene expression profinling of spontaneous and induced mammary tumors of the rat. Med. Vet. Diss. Hannover

McCue P. M. and Wilson W. D. (1989) Equine mastitis - a review of 28 cases. Equine Vet. J. 21, 351-353

Meuten D. J. (2002) Tumors of domestic animals. lowa. Blackwell, 576.

Munson L. (1987) Carcinoma of the mammary gland in a mare. J. Am. Vet. Med. Assoc. 191, 71-72

Platet N. (2004) Estrogens and their receptors in breast cancer progression: a dual role in cancer proliferation and invasion. Crit. Rev. in Oncol. 51, 55-67

Prendergast M., Bassett H. and Larkin H. A. (1999) Mammary carcinoma in three mares. Vet. Rec. 144, 731-732

Reef V. B. (1998) Ultrasonographic evaluation of small parts. In: Reef V. B., Equine diagnostic ultrasound. Saunders Company, Philadelphia, 522-523

Reppas G. P., McClintock S. A., Canfield P. J. and Watson G. F. (1996) Papillary ductal adenocarcinoma in the mammary glands of two horses. Vet. Rec. 138, 518-519

Rutteman G. R. and Misdorp W. (1993) Hormonal background of canine and feline mammary tumours. J. Reprod. Fert. Suppl 47, 483-487

Saji S. (2002) Expression of Estrogen Receptor (ER) cx protein in ER -positive breast cancer. Cancer Res. 62, 4849-4853

Schmah/ W. (1972) Solides Karzinom der Mamma bei einem Pferd. Berl. Münch. Tierarztl. Wochenschr. 85, 141-142

Seahorn T. L., Hall G., Brumbaugh G. W., Honnas C. M., Lovering S. L. and Snyder J. R. (1992) Mammary adenocarcinoma in four mares. J. Am. Vet. Med. Assoc. 200, 1675-1677

Spadari A., Valentini S., Sarli G., Spinella G. and Millanta F. (2008) Mammary adenoma in a mare: clinical, histopathological and immunohistochemical findings. Equine Vet. Educ. 20, 4-7

Surmont J. (1926) L'epitheliome mammaire de la jument et ses metastases pulmonaires. Bull. Ass. Franc. Etude Can. 15, 98-101

Theilen G. and Madewell B. R. (1979) Veterinary cancer medicine. Piladelphia. Lea \& Febiger, 192-203

Wilkock B. P. (1993) Pathology of Domestic Animals. Ed K. V. F. Jubb. P.C. Kennedy, N. Palmer, San Diego Academic Press. 706 